\title{
DISTRIBUTION OF A TRYPSIN-LIKE PROTEINASE IN THE RAM SPERMATOZOON
}

\author{
C. R. BROWN AND E. F. HARTREE \\ A.R.C. Unit of Reproductive Physiology and Biochemistry, \\ 307 Huntingdon Road, Cambridge CB3 0JQ
}

(Received 19th June 1973)

The trypsin-like proteinase (TLP) of rabbit spermatozoa (Stambaugh \& Buckley, 1969) attracted interest following the discovery that trypsin inhibitors impede the penetration of spermatozoa through the zona pellucida (Stambaugh, Brackett \& Mastroianni, 1969; Zaneveld, Robertson \& Williams, 1970). Stambaugh \& Buckley (1969) recovered most of this proteinase in an acrosomal fraction prepared by treating spermatozoa with the surfactant Hyamine 2389 (Hartree \& Srivastava, 1965). Using fluorescein-labelled trypsin inhibitors, they established for several mammalian species that TLP is restricted to the acrosomal region of the sperm cell (Stambaugh \& Buckley, 1970).

Difficulties arise when attempts are made to correlate this work with electron micrographic studies of the changes undergone by rabbit and rodent spermatozoa during egg penetration and with electron micrographs of spermatozoa treated with Hyamine. At the stage when a spermatozoon enters the zona pellucida, the acrosome has already undergone a degradation ('acrosome reaction') which results in the inner acrosomal membrane (i.a.m.) becoming the limiting membrane over the entire acrosomal region apart from its distal region, the equatorial segment (Bedford, 1968, 1971; Pikó, 1969). It has thus been assumed (Stambaugh \& Buckley, 1970; Bedford, 1970; Zaneveld, Robertson, Kessler \& Williams, 1971) that TLP, as a zona-penetrating enzyme, must be associated with the i.a.m. The standard treatment with Hyamine solubilizes most of the TLP of rabbit spermatozoa (Stambaugh \& Buckley, 1969) and also, as we have found, of ram spermatozoa. Nevertheless, it is established for bull (O'Donnell, Symons \& Wooding, 1970) and ram (Hartree, 1971) spermatozoa that such treatment leaves the i.a.m. attached to the sperm head. To obtain direct experimental evidence on the location of TLP in ram spermatozoa, we have developed a procedure for removing acrosomes which does not involve surfactants and which leaves the i.a.m. in situ.

The activity of TLP was measured at $25^{\circ} \mathrm{C}$ in a pH-stat with $\mathrm{N} \alpha$-benzoyl-Larginine ethyl ester (BAEE) (Walsh \& Wilcox, 1970). The assay system $(1.6 \mathrm{ml})$ contained $2 \mathrm{~mm}$-BAEE, $0.1 \mathrm{M}-\mathrm{CaCl}_{2}, 1.5 \mathrm{~mm}$-tris, plus $\mathrm{HCl}$ to $\mathrm{pH} 8.2$. Since ejaculated spermatozoa contain trypsin inhibitors, true measures of TLP content require that sperm fractions be acidified at $0^{\circ} \mathrm{C}$ to $\mathrm{pH} 2.5$ to dissociate inhibitor-enzyme complexes (Zaneveld, Dragoje \& Schumacher, 1972) before being added to buffered BAEE solution.

Ram semen $(16 \mathrm{ml})$ was diluted with 4 vol. sucrose-citrate (0.275 M-sucrose, 
16 mm-citric acid, $\mathrm{NaOH}$ to $\mathrm{pH} 6.5)$ and centrifuged at room temperature under conditions $(\sim 600 \mathrm{~g})$ that leave cytoplasmic droplets in the supernatant fraction (Allison \& Hartree, 1970). Sperm pellets must be loose enough to resuspend when the capped tubes are rocked gently. The cells were washed once with sucrose-citrate and once with 0.25 M-sucrose. The washed spermatozoa were resuspended in $0.25 \mathrm{~m}$-sucrose and stored at $-20^{\circ} \mathrm{C}$. To detach acrosomes, the frozen suspension was thawed, diluted with $0.25 \mathrm{M}$-sucrose to ten times original semen volume (o.s.v.) and stored at 20 to $22^{\circ} \mathrm{C}$ for $1 \mathrm{hr}$. Subsequent steps were effected at 0 to $5^{\circ} \mathrm{C}$. The suspension was agitated, in 10 -ml portions, with a whirlimixer (vortex mixer), this treatment being timed

Table 1. Fractionation of washed, whirlimixed spermatozoa (W) into denuded spermatozoa and two wash-fluids containing acrosomal material, followed by solubilization at $\mathrm{pH} 3$ of trypsin-like proteinase (TLP) in the denuded sperm fraction

\begin{tabular}{|c|c|c|c|c|c|}
\hline Exps & Fraction & $(U)^{\text {Full }}$ & $\begin{array}{l}\text { ctivity } \\
\text { elative values }\end{array}$ & $\begin{array}{c}\mathcal{N e t}(\text { inhibited }) \\
T L P \text { activity } \\
(U)\end{array}$ & $\begin{array}{c}\text { Cell count corrected } \\
\text { for dilution from } \\
\text { o.s.v. } \\
\left(10^{-9} \times \text { cells } / \mathrm{ml}\right)\end{array}$ \\
\hline 1 & $\begin{array}{l}\text { W } \\
\text { Wash-fluid } 1 \\
\text { Wash-fluid } 2 \\
\text { Denuded sperm. } \\
\text { Solubilized TLP }\end{array}$ & $\left.\begin{array}{c}75 \\
7 \cdot 3 \\
4 \cdot 7 \\
74 \\
83\end{array}\right\}$ & $\begin{array}{r}87 \\
100 \\
98\end{array}$ & $\begin{array}{l}33 \\
0 \cdot 5 \\
3 \cdot 5 \\
70 \\
84\end{array}$ & $\begin{array}{l}2 \cdot 5 \\
2 \cdot 4\end{array}$ \\
\hline 2 & $\begin{array}{l}\text { W } \\
\text { Wash-fluid } 1 \\
\text { Wash-fluid } 2 \\
\text { Denuded sperm. } \\
\text { Solubilized TLP }\end{array}$ & $\left.\begin{array}{c}68 \\
4 \cdot 4 \\
4 \cdot 6 \\
78 \\
88\end{array}\right\}$ & $\begin{array}{r}77 \\
100 \\
101\end{array}$ & $\begin{array}{l}20 \\
2 \cdot 5 \\
2 \cdot 6 \\
68 \\
85\end{array}$ & $\begin{array}{l}2 \cdot 4 \\
2 \cdot 0\end{array}$ \\
\hline
\end{tabular}

Units of activity (U) are $\mu \mathrm{mol}$ BAEE hydrolysed $/ \mathrm{min} / \mathrm{vol}$. of fraction derivable from $1 \mathrm{ml}$ semen. To

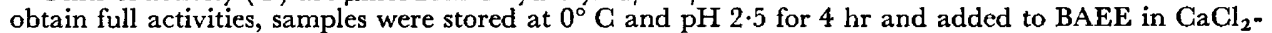
tris buffer. To obtain net activities, BAEE was added to fractions previously diluted with buffer. o.s.v.- original volume of ram semen.

(20 to $30 \mathrm{sec}$ ) to produce at least $50 \%$ of 'denuded' spermatozoa, i.e. spermatozoa that, under phase contrast, were recognizably without acrosomes. A sample of this suspension (W) was kept for analysis. The remainder was centrifuged ( $20 \mathrm{~min}, 500 \mathrm{~g}$ ), the cells were resuspended in sucrose, whirlimixed as before and centrifuged again. The spermatozoa, now virtually all denuded, were stored in $0.25 \mathrm{M}$-sucrose. The two supernatant wash-fluids, containing acrosomes and small particles, were kept. In electron micrographs, the denuded spermatozoa closely resemble published micrographs of Hyamine-treated spermatozoa (O'Donnell et al., 1970; Hartree, 1971), i.e. the plasma membrane is missing and over the entire acrosomal region (apart from the equatorial segment) the limiting membrane is the i.a.m.

To extract TLP from denuded spermatozoa, the suspension was stirred at $0^{\circ} \mathrm{C}$, cautiously acidified with $\mathrm{N}-\mathrm{HCl}$ to $\mathrm{pH} 3.0$ and centrifuged for $15 \mathrm{~min}$ at 20,000 g. A second extraction with $0.25 \mathrm{~m}$-sucrose $\mathrm{pH} 3$ (2×o.s.v.) left an enzymatically inactive residue. The combined acid extracts contained TLP in soluble form which was stable for several weeks at $5^{\circ} \mathrm{C}$.

Table 1 summarizes our results. The ram semen contained $\sim 3 \times 10^{9}$ cells $/ \mathrm{ml}$; 
thus the recovery of denuded cells was about $70 \%$. Losses occurred mainly through loose packing of sperm pellets during the washing of spermatozoa. Tighter packing improved recovery but damaged the cells. The combined activities of denuded spermatozoa and wash-fluids always exceeded the activity of $W$ from which the three fractions were derived. This may have been due in part to incomplete removal of acrosomes in $\mathrm{W}$. The wash-fluids and $\mathrm{W}$ contained considerable amounts of TLP inhibitor: however, removal of inhibitor in the wash-fluids left the denuded spermatozoa almost free of inhibitor. From the full activity values in Table 1 , it is clear that TLP was retained by ram spermatozoa during denudation. (Preliminary experiments indicate that the same holds for rabbit and bull spermatozoa.) Since TLP is restricted to the acrosome (including the equatorial segment-Stambaugh \& Buckley, 1970), we conclude that it is specifically associated with the i.a.m. although its distribution within the segment remains uncertain.

When denuded spermatozoa are added to the standard assay system, TLP is rapidly solubilized. If, in the assay system, $\mathrm{CaCl}_{2}$ is replaced by $0.25 \mathrm{M}$-sucrose, no solubilization occurs but, again, the activity of denuded spermatozoa is nearly as high as that of the acid extract. We therefore deduce that after the acrosome reaction occurs, the TLP bound to the i.a.m. is readily accessible to exocellular substrates.

Among marine invertebrates, lysins diffusing from spermatozoa can attack egg-membranes in advance of contact between the gametes (Wada, Collier \& Dan, 1956; Colwin \& Colwin, 1960). Passage of a mammalian spermatozoon through the zona pellucida, however, is a result of the cutting of a narrow hole with a cross-section no greater than the widest cross-section of the sperm head (Dziuk \& Dickmann, 1965; Yanagimachi, 1966; Bedford, 1970). This is consistent with the expected effects of a surface-bound sperm proteinase upon the zona substance. Bedford (1970) has raised the possibility that the zonapenetrating enzyme may be beneath the i.a.m., i.e. in the perinuclear space. We find that the TLP in whirlimixed spermatozoa is at least $98 \%$ sedimentable at $100,000 \mathrm{~g}$. This strongly suggests that any TLP beneath the i.a.m. is unlikely to diffuse through that membrane to become functional during zona penetration. There are reasons, however, for supposing that enzymes in spermatozoa, and especially in the equatorial segment, play a part in the fusion of spermatozoon with vitellus and perhaps in activation of the egg (Bedford, 1970; Hartree, 1971).

We are indebted to Mr G. C. Foster for counting cells with an Imanco Quantimet 720 Image Analyser Computer.

\section{REFERENCES}

Allison, A. G. \& Hartree, E. F. (1970) Lysosomal enzymes in the acrosome and their possible rôle in fertilization. 7. Reprod. Fert. 21, 501 .

BEDFORD, J. M. (1968) Ultrastructural changes in the sperm head during fertilization in the rabbit. Am. F. Anat. 123, 329.

Bedpord, J. M. (1970) Sperm capacitation and fertilization in mammals. Biol. Reprod. Suppl. 2, 128.

BEDFoRd, J. M. (1971) An electron microscopic study of sperm penetration into the rabbit egg after natural mating. Am. J. Anat. 133, 213. 
Colwin, L. H. \& Colwis, A. L. (1960) Formation of sperm entry holes in the vitelline membrane of Hydroides hexagonus (Annelida) and evidence of their lytic origin. 7. biophys. biochem. Cytol. 7, 315.

Dziuk, P. J. \& Dickmann, Z. (1965) Sperm penetration through the zona pellucida of the sheep egg F. exp. Zool. 158, 237.

HARTREE, E. F. (1971) Lysosomes and fertilization. In: Of Microbes and Life, p. 271. Eds. J. Monod and E. Borek. Columbia University Press, New York.

Hartree, E. F. \& Srtvastava, P. N. (1965) The chemical composition of the acrosomes of ram spermatozoa. F. Reprod. Fert. 9, 47.

O'Donnell, A. M., Symons, D. B. A. \& Wooding, F. B. P. (1970) Immunofluorescence and electron microscopy of acrosomes of bull spermatozoa. 7. Physiol., Lond. 210, 120p.

Pixó, L. (1969) Gamete structure and sperm entry in mammals. In: Fertilization, Vol. II, p. 325. Eds. C. B. Metz and A. Monroy. Academic Press, New York.

Stambaugh, R., Brackett, B. C. \& Mastroiann, L. (1969) Inhibition of in vitro fertilization of rabbit ova by trypsin inhibitors. Biol. Reprod. 1, 223.

Stambaugh, R. \& Buckley, J. (1969). Identification and subcellular localization of the enzymes effecting penetration of the zona pellucida by rabbit spermatozoa. $\mathcal{F}$. Reprod. Fert. 19, 423.

Stambaugh, R. \& Buckley, J. (1970) Histochemical subcellular localization of the acrosomal proteinase effecting dissolution of the zona pellucida using fluorescein-labelled inhibitors. Fert. Steril. 23, 348.

Wada, S. K., Collier, J. R. \& DAN, J. C. (1956) Studies on the acrosome. V. An egg membrane lysin from the acrosomes of Mytilus edulis spermatozoa. Expl Cell Res. 10, 168.

Walsh, K. A. \& Wilcox, P. E. (1970). Serine proteases. Methods in Enzymology, Vol. XIX, p. 37. Eds. G. E. Perlmann and L. Lorand. Academic Press, New York.

YANAGMACHI, R. (1966). Time and process of sperm penetration into hamster ova in vivo and in vitro. 7. Reprod. Fert. 11, 359.

Zaneveld, L. J. D., Dragoje, B. M. \& Schumacher, G. F. B. (1972) Acrosomal proteinase and proteinase inhibitor of human spermatozoa. Science, N.Y. 177, 702.

Zaneveld, L. J. D., Robertson, R. T., Kessler, M. \& Williams, W. L. (1971) Inhibition of fertilization in vivo by pancreatic and seminal plasma trypsin inhibitors. 7. Reprod. Fert. 25, 387.

Zaneveld, L. J. D., Robertson, R. T. \& Williams, W. L. (1970) Synthetic enzyme inhibitors as antifertility agents. FEBS Lett. 11, 345. 